\title{
THE REALITY OF CONTROVERSY
}

by Jay D. Hair

usanne Huttner says she has detected little concern about biotechnology in the U.S. in the round of meetings that she attends other than the highly publicized drama surrounding the ice minus release in 1985 ("The Value of Controversy," The Last Word, BiolTechnology p. 1400 Dec. 1991). She acknowledges a few voices, but dismisses them as "the same handful of individuals based in or around Washington." She then objects that agencies have allowed "special interest interference" from these few to replace "risk-based" triggers with "scientifically unsupportable process-based nets." As the President of the National Wildlife Federation, the nation's largest conservation education organization, I feel compelled to respond. Although Dr. Huttner apparently hasn't heard them, the voices in Washington and around the country concerned about agricultural biotechnology are numerous and growing. It is one thing to disagree with the voices of concern about biotechnology; it is another to refuse to acknowledge that they exist.

To make my point, I'd like to run through some of the groupsin addition to the Foundation on Economic Trends mentioned by Dr. Huttner-that I know are currently working to evaluate and influence the development of this new technology.

Three mainstream environmental organizations currently have at least one full-time staff person working on biotechnologythe National Wildlife Federation, the Environmental Defense Fund, and the National Audobon Society. The luxury of more than one professional in these groups is made possible by the farsighted grantmaking of the Joyce Foundation. Also, Friends of the Earth has worked on biotechnology issues for over a decade. Although small compared to the army of lobbyists, policy analysts amd public relations people fielded by the industry, this contingent of environmental professionals working on the issue is substantial. The handful of individuals so contempuously dismissed by Dr. Huttner represents not a de minimus level of concern but strong commitment by environmental organizations to this issue.

The staff of these organizations are not lone rangers. National Wildlife Federation policies, for example, are not set by national staff but by the 52 independent affiliates of the federation at an annual meeting held for that purpose. In four separate annual meetings, the National Wildlife Federation has passed policy statements, called resolutions, urging caution in the development of biotechnology, particularly in its environmental applications. Affiliates of the National Wildlife Federation have participated in various genetic engineering proceedings, including the test of the recombinant rabies virus in South Carolina, the transgenic fish experiments in Alabama, and proposed regulations governing environmental release in Minnesota.

Environmental groups are far from the only players in the biotechnology game in the U.S. There are numerous national, state and local groups forming around biotechnology issues or

Jay D. Hair is the President of the National Wildlife Federation, 1400 Sixteenth Street, N.W., Washington, DC 200362266, U.S.A. These views are the author's own, and are not necessarily those of Bio/Technology. adding these issues to their agendas. Below are some of the groups of which I am aware.

In the dairy states of Vermont and Wisconsin, Rural Vermont, the Family Farm Defense Fund, and the Wisconsin Rural Development Fund all work on dairy issues, bovine growth hormone and state environmental release regulation.

In the West, the newly formed Washington Biotechnology Action Council along with the California Biotechnology Action Council are state umbrella organizations focussed on biotechnology issues.

In the Midwest, the Minnesota Food Association works on reform of the land grant universities and state regulation of environmental release legislation. In addition, the Center for Rural Affairs in Nebraska and the Land Stewardship Project in Minnesota have provided critical views of agricultural biotechnology from their perspective as proponents of family farms and sustainable agriculture.

At the national level, groups outside the environmental community are involved in the issue. The Council For Responsible Genetics, for example, works on environmental release issues in addition to biowarfare, human gene therapy, and the human genome project. The Social Action Committee of the. United Methodist Church has engaged in an extensive two-year process to educate itself about genetic engineering and develop policies concerning it.

Other national groups which have voiced serious concerns about biotechnology include the Pesticide Action Network, the National Toxics Campaign, and the National Campaign Against The Misuse of Pesticides.

It is true that federal agencies provide an open door to public interest groups; after all we live in a democracy. But the overwhelming "special interest" representatives swarming in agency corridors are from industry. Indeed, at the White House's Council on Competitiveness, whose growing power threatens to dwarf all other regulatory entities, industry is the only interest whose views are taken into account.

Finally, on the matter of what to regulate. We do not subscribe to absolute safety or zero risk. Like Dr. Huttner, we favor riskbased regulations. We simply believe that where processes are employed that involve a substantial degree of uncertainty, process becomes a legitimate factor to consider in assessing risk. Our approach is admittedly more cautious than industry's, but not because we differ significantly on the assessment of the science. It is because we are trying to learn the lessons of our previous miracle technologies. In addition, and probably more importantly, the first products of agricultural biotechnology - bovine growth hormone and herbicide-tolerant plants-leave many people skeptical about the benefits of agricultural biotechnology to any but those in the chemical industry.

In sum, numerous voices have spoken out on biotechnology and can be heard by those who will listen. Indeed, these voices constitute a remarkable presence in a country that habitually prefers a dramatic response to a crisis to taking the action necessary to prevent one. These voices of concern need not be agreed with, but they cannot be ignored. 